\title{
CONFLICT OF LAWS ISSUES RELATED TO SECURITIES TRANSACTIONS
}

\author{
Oleksandr Vygovskyy \\ Department of Private International Law, Taras Shevchenko National University of Kyiv, Kyiv, Ukraine
}

\begin{abstract}
In this article we examine the conflict of laws issues of cross-border securities transactions. It deals with the problems of attributing lex situs to securities held under direct holding system and conflict of laws problems related to intermediated securities. We analyze possible variants of the conflict of laws rule for the securities and formulate our own attitude towards identification of the most efficient solutions of conflict of laws issues.
\end{abstract}

Key words

Securities, conflict of laws, issuer, securities' register, indirect holding system

\section{INTRODUCTION}

Private international legal aspects of securities transactions with a foreign element present a rather challenging area for researchers due to complex legal nature of the securities and their non-uniform characterization in various legal systems. The choice of this particular area for our research was made due to the apparent significance of the legal matters arising at the international securities market. The current trends in the financial world towards further globalization have caused a substantial increase of cross-border dimension of the securities' transactions. At the same time this sphere of conflict of laws undoubtedly lacks certainty in many aspects, vital for discovering "the closest and most identified link" of the said relationships with the competent jurisdiction. Theoretical ambiguity of these issues has given rise to substantial academic debate and remarkable controversy of the views and opinions in this regard. It is no exaggeration to say that there is apparently a considerable gap to be filled, and this article presents an attempt to explore some of the key issues of this fairly grey and ambiguous area.
Conflict of laws issues of the securities have rarely been the sole objects of fundamental studies. As valuable exceptions, we can cite the monograph of Maisie Ooi 'Shares and Other Securities in the Conflict of Laws' /1/ which examines in detail the choice of law treatment of securities transactions both in direct and indirect holding systems, as well as collection of articles on these topics contained in 'The Law of Cross-Border Securities Transactions' by Hans van Houtte /2/ providing a helpful insight into different aspects of international dealings in securities, including those held through depositories. Separate private international law aspects of securities were also elaborated in the study of Janeen M. Carruthers 'The Transfer of Property in the Conflict of Laws (Choice of Law Rules Concerning Inter Vivos Transfers of Property)' $/ 3$, works of Joanna Benjamin, such as 'The Law of Global Custody' /4/, the study of A.O. Austen-Peters 'Custody of Investments: Law and Practice' /5/ and some others.

The academic scholars who investigated these issues before focused primarily on possible adjustment of the classic lex situs rule in its application to the securities or their types. Some of the authors hold the view that situs of 
securities for the purposes of conflict of laws regulation should be connected with the place of location of a security certificate or place where the register is maintained /6-11/, while others equally reputable scholars and commentators give reasons for localization of securities at the place of incorporation of their issuer, completely rejecting lex registrationis approach /1, 5, 12/. In-depth analysis of academic literature on these problems allows us to conclude that difficulties with establishing a catchall conflict of laws rule for securities can be explained by failure to differentiate between various aspects (proprietary, obligatory, corporate, contractual etc.) arising in the context of securities relations, as well as by inability to have regard to peculiarities of legal nature of securities which determine specific paradigm for conflict of laws regulation of this type of property. Therefore, the conflict of laws issues arising in respect of securities need to be revisited and an alternative approach should necessarily be suggested, and this task is being resolved within the present article.

Due to equivocal legal nature of the securities, traditional approaches towards solving conflict of laws issues in respect of tangible movable assets and intangible assets appear to be futile and conventional situs rule in this case undeniably needs further revision. Irrespective of whether we characterize a security as a res or as a chose in action, customary practice of establishing lex situs will bring no effect when dealing with proprietary aspects of securities transactions. Furthermore, these issues need to be effectively addressed on a uniform basis, and a balanced approach should necessarily be introduced to deal with the conflict of laws problems in this field.

A further reason for such a choice lies in the fact that in terms of a substantial increase in cross-border securities transactions carried out through indirect holding system the general rules of determining the situs are no longer effective due to the intrinsic features of the intermediated securities. This invariably gives rise to the question as to whether the traditional situs rule should be adapted and further employed, or another paradigm should necessarily be evolved as a requisite substitute for the conventional situs approach.
It should also be noted at the outset that the present study is not intended to provide a detailed review of all private international law questions concerning every type of securities (which is apparently infeasible within the ambit of an article). Rather, the scope of this work is narrowed to the problems of determining situs of securities transacted through direct and indirect holding systems.

The range of problems raised in this article presents not only theoretical, but also practical significance. Legal regulation of cross-border securities transactions on international, regional and domestic levels lack a uniform, balanced approach, and this fact undermines certainty and predictability in the domain of such regulation. In most jurisdictions national codifications of private international law do not include even a single rule related to securities. The scope of legal systems being in potential conflict in respect of securities may be remarkable, including the law of the country of the issuer, the investors, the place of offering or transaction, place of location of a certificate, the law of jurisdiction of a depository institution or central securities depository. Solving this conflict of laws puzzle is unquestionably not an easy task.

The present article is aimed at bridging a gap in the universal doctrine of private international law and contributing to conceptual development of the principles of formulating conflict of laws rules in respect of securities which would correspond to the contemporary environment and problems arising in the area of cross-border securities transactions. Our present study is designed to eliminate deficiencies of the past researches and suggest the most efficient model for conflict of laws regulation of cross-border securities transactions with due regard to intrinsic features of their legal nature.

In this article we explore the dual legal nature of securities which affects its private international law regime and complicates solution of conflict of laws issues in their respect. The perception of securities as a bundle of underlying rights disables the option of mechanic application of traditional situs rule to securities without due regard to intrinsic features of particular categories of securities. In this context our task is to find out the main 'connect- 
ing' $^{\prime}$ characteristics of the securities that can determine situs of this kind of property. Further we are considering the results of substantial academic debate and various doctrinal views and opinions in this regard and are analyzing different possible variants of the conflict of laws rule determining situs of the registered and bearer securities. In particular, we examine two main approaches to establishing the governing laws for registered securities, namely lex societatis of the issuer and law of the place where the register is kept (lex registrationis), and suggest a more balanced 'split' approach based on a clear distinction between the issues of holding of the securities and proprietary and contractual aspects of transfer of title to the securities. Finally, we explore the conflict of laws issues in respect of intermediated securities held in indirect holding system and submit that traditional approaches (including 'look-through approach') are futile in this context. Instead, PRIMA should be treated as the most efficient solution for this problem, since it creates legal certainty and eliminates drawbacks inherent in traditional approaches.

\section{MATERIALS AND METHODS}

Formal legal approach laid the basis for establishment of the objective links of private legal relations with foreign element existing in respect of the securities with a particular legal system. Application of the formal logical approach proved to be useful when studying the process of formation and evolution of scientific approaches towards resolution of the conflict of laws problem related to proprietary aspects and transactions with securities in direct and indirect holding systems. Method of comparative legal studies appeared to be indispensable when studying the legislative rules, judicial cases and doctrinal approaches related to international securities transactions in various jurisdictions belonging to different legal systems.

The scope of doctrinal materials used within the present research included a wide range of general works in private international law and securities regulation, in particular, theoretical studies on legal nature of securities and works of prominent commentators on conflict of laws which constituted a starting point and concep- tual framework for our further investigation of designated issues. Our empirical data encompassed leading cases regarding title in securities which related to conflict of laws issues and provided their controversial solutions. In particular, we are referring to a classic case of Macmillan Inc. v. Bishopsgate Investment Trust plc (No 3) /13/ giving a vivid example of inconsistent and contradictory approach towards these issues. In this case all three Lords Justices opined different solutions trying to establish the most coherent localizing factor for the securities in question. This case is an undeniable milestone in the development of judicial approaches when tackling the conflict of laws issues related to securities and eloquently proves the need for a painstaking elaboration of such issues. We have also explored a range of international and domestic legal acts governing private international law aspects of securities transactions, in particular, the Hague Convention of 5 July 2006 on the Law Applicable to Certain Rights in Respect of Securities Held with an Intermediary which adopted and implemented PRIMA approach as the most efficient method of resolving the conflict of laws issues of intermediated securities. We have investigated these materials and data to produce a viable mechanism for establishing legal systems to govern various types and categories of securities.

\section{RESULTS AND DISCUSSION}

The main objective of this research is to elaborate legal doctrinal issues arising in respect of conflict of laws regulation of securities, generalization of the existing approaches towards formulating of scientific proposals regarding resolution of these issues by means of private international law instruments. For attainment of this objective we will consider mechanism of solving conflict of laws issues related to the securities and study the conceptual approaches in legal doctrine and practice and main trends which have determined the development of legal thought in this field.

Securities are traditionally viewed as a rather specific kind of property. In fact, "identifying something as a security causes a dramatic change in its legal environment" /14/. The complexity of their legal nature is intrinsically 
rooted in the dual approach to their essence. On the one hand, the securities, being personal property (movable res), can be pledged, sold, bought or otherwise transferred into the ownership. On the other, a security as a piece of paper is worth of nothing: it has its material value because of a bundle of rights conferred by its issuer. It is this distinctive feature of a security that determines its unique positioning among movables as a chose in action, rather than a chose in possession.

Historically, the securities were designed to facilitate the negotiability of the aforesaid bundle of rights. In particular, a documented share is a materialized form of corporate rights that cannot be assigned without transferring the share itself. Furthermore, these rights form an aggregate, implying that they cannot be separated and can be transferred to another person only in extenso. For instance, a shareholder can't assign a right of voting at the general meetings of shareholders, leaving the right of sharing in the company's profits by receiving dividends. Taking these distinctive features into consideration, legal doctrine emphatically upholds the notion of the dual legal nature of a share. As $\mathrm{M}$. Ooi indicates, the rights by themselves, even when aggregated, do not form the share; rather the share is an aggregate of all the rights and obligations contained in the statutory contract $/ \mathbf{1} /$. It is this sum of rights and duties in the companyshareholder relationship that defines a share /1/. A. Briggs believes, that "the process misdescribed as 'share transfer' is in fact the surrender and re-grant of rights in the company" /12/.

This dualism of legal nature of the securities forces us to make a clear distinction between the bundle of rights, represented by a security, and the property rights of ownership to the securities. It is absolutely evident that they are tightly interlinked, implying that a person owning a security can dispose of any rights conferred to him by the issuer, and thus, transfer of a security certificate entails a simultaneous transfer of all and any rights which, in the aggregate, constitutes the essence of the security. In case of a registered security any person named in the register can dispose of any rights, which he or she has by virtue of possession of a security; in case of a bearer share, these rights are presumably conferred to the person holding a security certificate.

These distinctive features of the securities brings us to the following fundamental notion vital for the purposes of our research: a documented security vesting its owner with a bundle of rights, and a security certificate as a document attesting these rights are not the same things and indubitably should be considered separately when analyzing the transfer of securities and transactions connected herewith. In particular, if a shareholder transfers a certificate of a registered share to another person who is not entered in the register of the shareholders as an owner of a share, such transferor will still be considered as a shareholder, having all the rights stipulated by the issuer's constitution and applicable legislation. Only in case of bearer shares, transfer of a share certificate will immediately result in the transfer of corporate rights embodied in the share.

The traditional conflict of laws approach with regards to shares is that "questions relating to title to shares are to be governed by the law of the situs of the shares" /9/. As a rule, the law of property considers situs as "the place where property rights can be enjoyed or made effective" $/ \mathbf{1 5} /$, or as a place where a thing actually situates. But what is lex situs in relation to securities? At first sight, the choice of law solution with respect to the documented securities is fairly straightforward: situs should prima facie be defined as a place of location of a security certificate, which often coincides with lex loci actus of the securities transaction.

However, as we have pointed out above, a security certificate is not a security itself; a security as a bundle of rights is an abstract thing, an intangible property, the situs of which cannot be associated with the location of a certifying document. Therefore, our task is to find out the main 'connecting' characteristics of the securities that can determine situs of this kind of property.

The problem becomes even more acute in cases of non-documented securities which are traditionally deemed to be intangible or incorporeal movables. Long and heated debate as to "whether a debt is a thing that can be located in space" /16/ was a remarkable milestone in the legal doctrine. As J. G. Collier reasonably argues, "unlike a piece of tangible property an 
intangible one does not physically exist, and so, obviously, cannot really be situated anywhere. But since it has a legal existence, the law can and does ascribe a situs to an intangible" $/ \mathbf{1 0} /$. In fact, "the situs is a legal fiction which will differ with the kind of intangibles involved, and with the purpose for which it is being determined" /17/. Thus, lex situs with regards to intangibles means a presumable (fictional), rather than a physical location. It should also be taken into consideration that legal location, determined as situs, and physical location are not necessarily congruent. The difficulty with an appropriate choice of law is caused by the above-mentioned inextricable legal nature of a security, as well as the fact that "more than one jurisdiction may be said to be able to exercise that power legitimately" /1/. Theoretical ambiguity of issues outlined above has given rise to substantial academic debate and remarkable controversy of the views and opinions in this regard. Firstly, the traditional situs rule undeniably needs proper adjustment when solving the proprietary issues of this specific kind of intangible movables due to its equivocal legal nature. Secondly, the questions arising in respect of cross-border securities transactions need to be effectively addressed on a uniform basis, and a balanced approach should necessarily be introduced to deal with the conflict of laws problems in this particular field.

There are different possible variants of the conflict of laws rule determining situs of the securities, including lex societatis of the issuer, law of the place where the securities register is kept (in case of documented securities) or law of the place where the securities depository is situated (in case of non-documented securities), law of the place of location of a security's certificate, law of the state of registration of the securities issue, lex loci actus of the securities transaction, lex personalis (lex patriae or lex domicili) of the owner of the securities.

It is a widespread notion in the conflict of laws doctrine that shares are deemed to situate in the country, where they can be effectively dealt with as between the shareholder and the company $/ 9,11 /$. At the same time, the choice of competent jurisdiction will evidently depend upon the category of the shares in question registered or bearer.
Registered securities are those any transactions with which can only be effected by making a special entry on a register. As a rule, this register is situated in the issuer's country. However, if an issuing company transacts business in a certain country outside the jurisdiction of its incorporation, it may cause to keep there a branch register of the members resident there. In such a case we have an explicit conflict between two different jurisdictions competing to determine the situs of the securities: lex societatis of the issuer and the law of the place of the register.

Many leading experts in private international law appear to share a view, either with reservations or not, that registered shares shall be deemed to be situated in the country where the register is kept /6-11/. Even if the issuer and the registrar have the same jurisdiction, the law of the place of the register shall undoubtedly be the ultimate determinant of the final choice. Sometimes reference is made on the Council Regulation (EC) 1346/2000 on Insolvency Proceedings, where Art. 2(g) stipulates that location of property and rights of ownership of or entitlement to which must be entered in a public register shall be deemed as the Member State under the authority of which the register is kept $/ 4 /$.

But other equally reputable sources of the contemporary conflict of laws doctrine and case law consider lex societatis to be the best choice of law for registered securities, entirely disregarding the place of the register. For example, A. Briggs holds the view that "assignments of registered shares are governed by the lex incorporationis for the pragmatic reason that any solution which departs from the law of the place of the share register is futile" /12/. Aldous L.J. in the case of Macmillan Inc. v. Bishopsgate Investment Trust plc (No 3) /13/ also maintains this position asserting that shares are property in the nature of a chose in action, which is immoveable in the sense that it remains at the place of the company's incorporation.

Having analyzed different approaches towards the solution of this conflict of laws issue, M. Ooi is of the same view, arguing that "the law of the situs of the register rule... is inappropriate as a matter of theory and practice" /1/. A. Johnson makes an observation that "inscrip- 
tion on a share register situated abroad is valid only because the personal law of the company gives effect to it" and then comes to the overall conclusion that "the personal law of the corporation is central". A.O. Austen-Peters goes further suggesting that "it may be a useful development for the use of situs in determining the applicable law for registrable securities to be abandoned and regard simply to be had to the law of the place of incorporation of the issuer of the securities" /5/.

Such a choice of law is usually reasoned by 'the internal affairs doctrine', that presumes that all the issues arising inside a company (e.g. relations among shareholders and management) shall be governed by the law of incorporation. It is also frequently argued to be the most 'stable' choice of law as "it does not depend on the place where the transaction takes place" /1/. Staughton L.J. in Macmillan Inc. $v$. Bishopsgate Investment Trust plc (No 3) /13/ appears to hold the same view emphasizing that the law of incorporation "have the advantage of pointing to one system of law which is very unlikely to be transient, and cannot be manipulated by a purchaser of shares in order to gain priority".

Finally, as securities are invariably deemed to belong to intangible property, the situs for which is tightly linked with the jurisdiction where an intangible right can be effectively enforced, and such "enforcement will be readily achievable at the place where the debtor resides" /3/, thus choice of law rule governing securities seems to be logically justified to be connected with the place of the securities' issuer.

In our opinion, solving the conflict of laws problems with regards to the securities, we should make a clear distinction between the issues of holding of the securities (i.e. the issues connected with the 'issuer-investor' relationship), on the one hand, and proprietary and contractual aspects of transfer of title to the securities, on the other. For these purposes it is suggested to treat the first set of issues stated above as 'statics' of the legal relationships related to the securities, as opposed to 'dynamics' determining the transfer of title to the securities. Our main standpoint is that different conflict of laws rules should be applied to statics and dynamics related to the se- curities, and such a solution will help us avoid superfluous theoretical debates outlined above.

Apparently, lex societatis is the primary conflict of laws rule with respect to any securities (whether registered or bearer) as their distinction concerns only the way of transfer of title to securities (by means of entry in the register or by mere delivery of a certificate). The characterization issues of the securities (their classification and qualification), the scope of rights attested by the securities and the way of their realization, transferability of the securities and corporate formalities for their transfer, - all these matters concerning the relationship between the investors and the company, which were labeled above as statics of the relationship in respect of the securities, should be implicitly governed by the personal law (lex societatis) of the issuer as having the closest and most real connection with them and constituting the law of the place of the 'creation' of securities (lex creationis).

Contrariwise, the proprietary aspects of transfer of title to documented securities (other than in the process of their placement) should obviously be governed by the law of the place where the securities are presumably 'situated' (bearing in mind the hypothetic character of such 'situation') at the time of the respective transaction. Apparently, this place will be different for registered and bearer securities.

The law of the place where a register is kept should undoubtedly be recognized as the law which governs the transfer of title to registered securities. It is this location that determines, inter alia, the way of transfer, all the formalities pertaining to the transfer of title to securities (apart from general prerequisites for transferability and corporate restrictions (for example, pre-emption rights), which shall be governed by lex societatis), as well as the moment of its transfer and its effects.

The case of London and South American Investment Trust, Limited v. British Tobacco (Australia), Limited /18/ may be regarded as a vivid illustration of the feasibility of the above principle. The English court held that the shares of a company with its head office in Australia owned by an English company were locally situated in England as one of the registers of shares was kept in London, and it was through 
the English register alone that the shares of the plaintiff company could be actually transferred.

The case of Macmillan Inc. v. Bishopsgate Investment Trust plc. /13/ deals with the bona fide acquisition of shares pledged by a person having no title to them. The defendants argued that the law of New York, being simultaneously the law of incorporation of the issuer, the law of the place where the relevant transfer took place (lex locus actus) and the law of the place where the shares were situate when the transaction took place (lex situs), should be invariably deemed as the governing law. Alternatively, the plaintiff insisted that his claims must be determined in accordance with English law as the law with which it has the closest and most real connection'.

The court of first instance rejected the law of incorporation, holding that the issues of priority, relating to the effect of shares transfer, in this case indispensably fall to be determined by the lex loci actus /13/, which, in its judgment, also coincides with the lex situs, being inevitably the law of New York. All three Lords Justices adopted the situs approach, though having distinct views on which law determines the situs of shares. In his court speech Auld L.J. assumed that the lex situs should normally be the country where the register is kept, which usually, but not always, coincides with the country of incorporation /13/. Aldous L.J., on the contrary, held the view that "shares are property which is situated in the country of incorporation and it is the law of that country which should be applied when determining questions of ownership /13/. Staughton L.J. held a moderate position, arguing that lex situs "is the law of the place where the company is incorporated", though admitting that "there may be cases where it is the law of the place where the share register is kept..." /13/.

Curiously enough, the final judgment does not contain the explicit answer to the question, which law in principle should be regarded as lex situs of registered shares (it is commonly know that even when applicable law has been determined, not all judges will apply it in the same way /6/. The Court of Appeal simply suggested that, in the case of shares, the issue should be determined by law of the place where the shares are situated. But two main points remain perfectly clear: the place of transaction (lex loci actus) is irrelevant when considering the issues of title to shares; the contractual aspects of transfer of title to shares and the proprietary issues of shares should be split and analyzed separately in the conflict of laws. In other words, the dual legal nature of securities described above determines the application of a 'dual conflict rule' with regards to securities.

Unlike registered securities, bearer securities, being transferred merely by delivery of their respective certificates, without making any formal acts prescribed by the issuer's constitution or applicable statutes, and thus being "fully embodied in the certificate" /1/, should be deemed to be invariably located in the place where the certificate is situated. Such variation of the situs rule in respect of the bearer securities is known as lex cartae sitae.

As to the contractual aspects of the securities transactions (including material and formal validity of a contract, interpretation of the contract, performance of the contract, consequences of a breach of the contract, various ways of extinguishing obligations, prescription and limitation of actions, and the consequences of the nullity of the contract), this broad spectrum of issues should irreversibly be governed by the proper law of the contract, which in the contracts for the sale of goods is usually associated with the place of residence or business of the seller which is to effect the characteristic performance under the contract.

In the contemporary capital markets securities are issued and transferred predominantly in a dematerialized (non-documented) form. In contradistinction from traditional securities, the only evidence of holding of dematerialized ones is an electronic book-entry on a special securities account in the relevant system (that's why they are also sometimes referred to as "intermediated book-entry securities" /19/. The relationships between the parties to a securities transaction are more complicated due to the existence of special intermediaries without which no transfer of title or collateral transaction can be effected.

The primary feature of this system is that the securities are not registered in the name of the investors, but rather in the name of the relevant intermediary, and there may be more 
than one intermediary involved. The name of the ultimate investor is not reflected in such a register, so his ownership cannot be proved neither by an entry in the records, nor by a certificate. As J. Benjamin stresses, "participants' interests constitute indirect, unallocated and intangible proprietary rights, based on coownership" /20/.

Holding of dematerialized securities within indirect holding system create additional difficulties in solving conflict of laws issues and uncertainty as to which law shall be deemed as applicable. They invariably give rise to the question as to whether lex situs can help localizing the intermediated securities, and if so, in which modification. It is suggested that difficulties relating to conflict of laws issues in securities arise from the fact that it is difficult to determine the location of intermediated securities /21/. Possible solutions of this problem conventionally include lex societatis of the issuer, law of the place of the register (computerized database) run by an intermediary, law of the place where an immobilized certificate situates (in case of immobilized securities), lex loci actus of a securities transaction in question and law of the place of the intermediary. Obviously, "such legal uncertainty operates as a deadweight cost on local, national and global economies" /22/.

The courts may try to treat the nondocumented securities held through intermediaries as the traditional securities, using the same principles of localization, as were mentioned above. Indeed, if "immobilised securities are akin to registered securities" /20/ as intangibles, why the custodian's database cannot be viewed as a proximate analogue of the securities' register?

Conflict of laws puzzle may appear to be even more complicated assuming that in the indirect holding system an investor is likely to hold not the securities of a single issuer, but rather a portfolio of securities issued in different jurisdictions, and this portfolio can often be used as collateral. In this context, assuming that the situs of such securities is determined by lex societatis of the issuer, a single competent jurisdiction for such a mixture of shares can hardly be précised.

It should be noted that in the era of globalization the new approaches seek to determine the applicable law by a functional connecting factor $/ 23 /$. The traditional situs approach (it is sometimes referred to as 'look-through approach') of attributing lex situs to book-entry securities is completely unacceptable due to its ignorance of the specific nature of multi-tiered indirect holding system, as well as its failure to find the proper law in case of diversification of a securities' portfolio. These drawbacks have led to a significant shift away from the traditional determination of situs of the securities as their presumable location towards the law of the place where the records of title to such securities are kept and where such securities can be effectively dealt with. In legal doctrine and practice such an approach is universally known as PRIMA, which stands for the 'Place of the Relevant Intermediary Approach'.

The connecting factor revealing the 'closest and most identified link' of the relevant relationship in this situation is explicitly of the contractual origin, as an investor has a merely contractual right of claim to the relevant intermediary, and the applicable law should be determined by the rules adopted for the specification of the proper law of the contract. It is universally recognized that the contract is most closely connected with the country of the party who is to effect the performance which is characteristic of the contract. In case of a securities account agreement (custody agreement) such a party is undoubtedly an intermediary (custodian).

Hence, the PRIMA approach is not a further extension of a traditional 'situs approach' and, in fact, creates no surplus legal fictions; rather, it tries to shift an emphasis from localization of the securities existing in a 'virtual', intangible form, to the contractual nature of rights of the owner to these securities. That's why it easily overcomes one of the major impediments of the 'situs approach' stated above: the diversity of the investor's portfolio composed of the securities of issuers from different jurisdictions does not prevent from determining a single competent jurisdiction. Furthermore, PRIMA allows entire accounts to be used as collateral, even if they contain securities from various jurisdictions $/ 24 /$.

It is unsurprising that PRIMA has been successfully adopted in the Hague Convention of 5 July 2006 on the Law Applicable to Certain Rights 
in Respect of Securities Held with an Intermediary, drafted and adopted under the auspices of the Hague Conference on Private International Law. A modification of this rule is embodied in the key provision of Article 4 of the Hague Securities Convention 2006, stating that the law applicable to all the issues falling under the scope of the present Convention is the law governing the accounts agreement. At the same time such a choice may not be deemed as unlimited: it will be applicable only if the relevant intermediary has an office at that state. Article 5 of this Convention provides for the 'fallback rules' designed for the cases if the applicable law is not determined according to Article 4 . The first of them implies the applicability of the law of the state where the intermediary's office is situated if it is expressly stated in a written account agreement that the relevant intermediary entered into the account agreement through that particular office. If the applicable law cannot be determined under this rule, it presumes that the governing law shall be lex societatis of the relevant intermediary by which it implicates the law under which it is incorporated or otherwise organized, or in which it has its primary place of business. Thus, this Convention entirely disregards 'look-through approach' as totally inadequate to the specific features of the intermediated system of securities' holding.

\section{CONCLUSIONS}

Having scrutinized different approaches to the solution of conflict of laws problems regarding securities transactions, we have come to the following principal conclusions:

1. Traditional situs rule undeniably needs proper adjustment when solving the conflict of laws issues related to securities due to their dual legal nature. This results in more complex choice of law approaches as compared to other (purely tangible or intangible) property.

2. The situs of securities is connected with the place where they can be effectively dealt with as between its holder and the issuer. This place should be localized, given the category of securities (registered or bearer), as well as the nature of the legal relationships involved.

Lex societatis of the issuer shall govern all the issues concerning the relationship between the holders and the issuer, regardless of type of securities. The proprietary aspects of transfer of title to documented securities should be governed by the law of the place where the shares are "situate" at the time of transaction. This place for registered securities shall be deemed as the place where a register is kept, and for bearer shares - as the place where a certificate is located. The contractual aspects of transfer of title to securities should be governed by the proper law of the contract.

3. Traditional conflict of laws approaches as to the dematerialized securities held through intermediaries are far from being adequate. The "look-through" approach is unacceptable due to its ignorance of the specific nature of multi-tiered indirect holding system. The connecting factor in the legal relationships between a customer and an intermediary is of contractual origin as an investor has a purely contractual right of claim to the relevant intermediary. The most adequate approach is PRIMA pointing to the law of the place of an intermediary as the party who is to effect the characteristic performance of the securities account agreement (custody agreement).

Notes

/1/ M. Ooi (2003). Shares and other securities in the conflict of laws, Oxford University Press on Demand.

/2/ H. Van Houtte (1999). The law of cross-border securities transactions, Sweet \& Maxwell.

13/ J. M. Carruthers (2005). The Transfer of Property in the Conflict of Laws: Choice of Law Rules in Inter Vivos Transfers of Property, OUP Catalogue.

/4/ J. Benjamin (2002). The Law of Global Custody. $2^{\text {nd }}$ ed., London: Butterworths, pp. 276.

15/ A. O. Austen-Peters (2000). Custody of investments: law and practice, Oxford University Press.

/6/ J.-G. Castel (1960). Private International Law: A Comparative Study of the Rules Prevailing in Canada and the United States, Toronto: Canada Law Book Co Ltd, pp. 326.

/7/ R. H. Graveson (1974). Conflict of Laws. Private International Law, London: Sweet \& Maxwell, pp. 675.

18/ E. B. Crawford (1998). International Private Law in Scotland, Edinburgh: W. Green / Sweet \& Maxwell, pp. 496.

19/ P.M. North; J.J. Fawcett (1999). Cheshire and North's private international law, Butterworths, London, pp. 434. 
/10/ J. G. Collier (2001). Conflict of laws, $3^{\text {rd }}$ ed., Cambridge: Cambridge University Press, pp. 403.

/11/ L. Collins (2006). Dicey, Morris and Collins on the Conflict of Laws, $14^{\text {th }}$ ed., London: Sweet \& Maxwell, pp. 2.

112/ A. Briggs (2002). The Conflict of Laws, Oxford: Oxford University Press, pp. 266.

/13/ Macmillan Inc. v. Bishopsgate Investment Trust plc and Others (1995). No 3; 1 W.L.R. 978 (Ch. D.), (1996) 1 W.L.R. 387 (CA).

/14/ N. L. Georgakopoulos (2005). Principles and Methods of Law and Economics, Cambridge University Press, UK, pp. 392.

/15/ I. F. Baxter (1966). Essays on private law: foreign law and foreign judgments, University of Toronto Press.

/16/ J. R. Rood (1905). Exit of the Doctrine of Situs, Central Law Journal, 61, pp. 265-270.

/17/ G. Van Calster (2016). European private international law, Bloomsbury Publishing.

/18/ London and South American Investmant Trust (1927), Limited v. British Tobacco (Australia), Limited 1 Ch. 107.
/19/ R. Potok; M. Moshinsky (1998). Cross-border Collateral: A Conceptual Framework for Choice of Law Situations, Butterworths Journal Of International Banking And Financial Law, 13, pp. 10-17.

/20/ J. Benjamin (1998). Recharacterisation Risk and Conflict of Laws, Butterworths Journal Of International Banking And Financial Law, 13, pp. 2937.

/21/ H. D. Vauplane (2018). Blockchain and Intermediated Securities, Nederlands Internationaal Privatrecht, 36, pp. 94-103.

/22/ R. D. Guynn; N. J. Marchand (1999). Transfer or Pledge of Securities Held Through Depositories, The Law of Cross-Border Securities, London: Sweet \& Maxwell.

/23/ D. Yokomizo (2015). Conflict of Laws in the Era of Globalisation, Japanese Yearbook of International Law, pp. 179-194.

/24/ P. Paech (2016). Securities, intermediation and the blockchain: an inevitable choice between liquidity and legal certainty? Uniform Law Review, 21(4), pp. 612-639.

\title{
KOMUNIKACIJSKI ZAKONSKI PROBLEMI U TRANSAKCIJI VRIJEDNOSNIH PAPIRA
}

\author{
Oleksandr Vygouskyy
}

Odjel za privatno međunarodno pravo, Taras Shevchenko nacionalno sveučilište Kijeva, Kijev, Ukrajina

\section{Sažetak}

U ovom članku ćemo ispitati sukob zakona pitanja prekograničnih transakcija vrijednosnih papira. Bavi se problemima pripisivanja lex situs vrijednosnim papirima držanim pod izravnim držanjem i problemima sukoba zakona vezanih uz posredovane vrijednosne papire. Analiziramo moguće varijante pravila sukoba zakona za vrijednosne papire i formuliramo vlastiti stav prema identifikaciji najučinkovitijih rješenja sukoba zakonskih pitanja.

\section{Ključne riječi}

vrijednosni papiri, sukob zakona, izdavatelja, registra vrijednosnih papira; neizravni sustav držanja 